\title{
CALM1 wt Allele
}

National Cancer Institute

\section{Source}

National Cancer Institute. CALM1 wt Allele. NCI Thesaurus. Code C51105.

Human CALM1 wild-type allele is located within 14q24-q31 and is approximately $11 \mathrm{~kb}$ in length. This allele, which encodes calmodulin protein, is involved in cellular growth, cell cycle regulation, signal transduction and the synthesis and release of neurotransmitters. 